\title{
Carta para o comitê editorial da Topoi
}

Ao longo da minha vida acadêmica, sempre fui um defensor intransigente do exercício da crítica de pensamento. Entendo a universidade como o espaço por excelência para discussão e divergência de ideias. Esse é o único caminho para a produção de um conhecimento de excelência. Entretanto, para isso ocorrer é necessária a observação de procedimentos rigorosos. Um artigo, uma resenha ou outra peça de circulação acadêmica precisa observar determinadas regras formais. No caso de uma resenha, cumpre lembrar que um periódico acadêmico difere de um jornal de notícias. Escrevi vários textos criticando ideias e diversos outros artigos foram publicados contrariando as minhas hipóteses. Aliás, para um pesquisador é sempre bom ver suas hipóteses tornarem-se objeto de artigos e de trabalhos finais de pós-graduação. Isto é indício do impacto da sua investigação na comunidade científica. Sempre entendi como uma prática do ofício que uma pesquisa deve ser arguida. Provavelmente vocês conhecem o ditado: todo bom trabalho nasce morto, pois ao ser lido ele é ultrapassado.

Pelas razôes expostas, me senti muito desconfortável ao ver "A formação da economia cafeeira do Vale do Paraíba" entre as resenhas aceitas pela Topoi. Que fique bem claro que o desconforto não resulta das opinióes críticas do autor a um livro de minha autoria, intitulado Baróes do café e sistema agrário escravista: Paraíba do Sul, Rio de Janeiro (1830-1888). Ela se deve, sim, ao fato de eu acreditar que a suposta resenha está longe de ser, de fato, uma resenha crítica. Uma resenha crítica deve ser entendida como um instrumento acadêmico em prol da produção e divulgaçâo do conhecimento. Ressalve-se, porém, que compreendo, o que quero enfatizar, a boa intençáo da revista em publicar a mesma. Muito provavelmente, o que se buscava era suscitar debate; afinal, esse é um dos traços da Topoi. No entanto, a discussáo acadêmica pressupóe respeitar regras formais. No caso de uma resenha, para que possa ser objeto de uma resposta, ela deve ser, antes de tudo, uma recensão acadêmica. $\mathrm{Na}$ verdade, sou de opinião de que a seção de resenhas, em função da sua própria natureza, diferente da seção de artigos, não deve ser locus de réplicas e tréplicas. Insisto, o desconforto não resulta das opinióes dos autores, mas sim do veículo no qual foram publicadas. Sabemos que um texto para ser chamado de resenha precisa obedecer a alguns pré-requisitos, quais sejam: apresentar à comunidade científica informaçóes fundamentais sobre a obra apreciada e que à apresentação se sigam observaçôes críticas. Desse modo, uma recensão crítica deve obrigatoriamente conter, entre outras, as seguintes características:

1- Origem, época e objetivos da pesquisa-base do livro.

2- Apresentação das principais hipóteses, das técnicas e dos métodos de investigação usados na construção da publicação. 
3- Estrutura da obra: número de capítulos, com uma rápida descrição do seu conteúdo (temas, fontes etc.).

Em geral, esses itens têm sido considerados para o aceite de escritos presentes na seçáo Resenhas de ediçôes da Topoi. Todavia, infelizmente, o mesmo não ocorreu com a publicação do escrito "A formação da economia cafeeira do Vale do Paraíba".

Depois da leitura do referido texto, o leitor não é brindado com nenhum daqueles itens. Logo, infelizmente, a suposta resenha é feita da maneira incompleta. O público da Topoi, após ler "A formação da economia cafeeira do Vale do Paraíba", jamais saberá que Barôes do café e sistema agrário é formado, por exemplo, por três capítulos. Ele ainda desconhecerá que os dois primeiros capítulos correspondem, em essência, à última parte de uma tese de doutorado defendida em 1990. Da mesma forma, o leitor não saberá que os ditos capítulos são resumos de uma pesquisa de história econômica, de base serial, feita conforme os cânones da década de 1980; o livro contém, portanto, uma infinidade de tabelas e gráficos. Assim, ao editar Baróes do café, optei por reduzir essas ilustrações, o que foi dito na introdução da obra. Ademais, aconselhei aos incautos interessados consultarem o trabalho original.

Outrossim, o público da Topoi também não é informado, pelos motivos já ditos, sobre os temas de cada capítulo (tópico 3 acima). No primeiro capítulo, por exemplo, trato dos traços gerais do sistema agrário (demografia, técnicas e sistema de uso da terra, estratificação por fortunas, distribuição de investimentos etc.). No segundo, procurei ver o comportamento daquele sistema agrário e seus estratos de fortunas na passagem do tempo, ou seja, em meio a conjunturas. Aliás, o único segmento do livro escrito pouco antes de sua publicação, em 2013, foi uma parte da introdução, intitulada "Notas para o estudo de duas elites agrárias da capitania do Rio de Janeiro (séculos XVII e XIX)", no qual ensaio algumas ideias comparativas sobre os diferentes comportamentos econômicos da nobreza da terra seiscentista do Rio de Janeiro e os baróes do café.

Por seu turno, em razão de os Baróes do café ser parte de uma tese defendida há cerca de 25 anos, era de se esperar que o leitor pudesse ser noticiado, pelo resenhista, sobre o seu impacto na área de investigação correspondente. Claro está que tal preocupação e exercícios só poderiam ocorrer a um especialista da área. Claro está, também, que tudo isto dá muito trabalho para quem se propõe a fazer uma recensão crítica. Não custa insistir: uma resenha é um trabalho acadêmico e não um simples resumo de opiniôes.

Igualmente, o leitor não é esclarecido sobre o conteúdo do terceiro capítulo. Este último, elaborado em 2003, tem por objeto a cidade do Rio de Janeiro, entre 1850 e 1888, como uma praça de negócios em uma economia de base escravista e ainda dominada pelo capital mercantil e por negócios rentistas. Também o leitor não é lembrado de maneira correta das minhas próprias críticas à pesquisa original que redundou em Baróes do café, passados 25 anos do trabalho original. Os problemas metodológicos por mim mencionados não dizem respeito - como foi sugerido pelos autores de "A formação da economia cafeeira do Vale 
do Paraíba" — à representatividade da amostragem ou às técnicas seriais usadas. Sobre esses tópicos, o meu livro sabe se defender. Aliás, foi em razão do suporte empírico e da contribuição metodológica (no caso, uso serial de escrituras cartorárias), ao menos na minha opinião, daqueles capítulos que os retirei do fundo do disco rígido de um computador. Os meus problemas metodológicos com Baróes do café são de outra natureza. Na década de $1980 \mathrm{eu}$ desconhecia os procedimentos da micro-história italiana, a exemplo do cruzamento do método onomástico com abordagem relacional apontada por E. Grendi. Hoje, procuraria, por exemplo, analisar as agências dos barôes como resultado de opçôes em meio à dinâmica das teias das relaçôes sociais. E entre os agentes de tais teias destacaria mais a açáo dos escravos. Por último, quem ler a referida resenha não é informado que em Baróes do café alerto sobre as dificuldades, em razão do estágio das pesquisas com cuidadosa demonstração empírica, de formular interpretaçóes gerais sobre a economia escravista do Brasil oitocentista e suas conexóes com o mercado internacional da época. Isto, para além de outras obviedades. Consequentemente, sou cauteloso e desconfio de muitos dos modelos econômicos explicativos para o século XIX. Nesse ponto, é sempre um bom exercício reconhecer a própria ignorância e ter claro os limites dos modelos ensaísticos. Eles são sempre provisórios, em especial, aqueles sem fortes evidências empíricas.

Portanto, parece-me da maior importância que o Conselho Editorial da Topoi reveja em profundidade seus critérios de aceitação das resenhas a serem publicadas, visando o cumprimento dos pressupostos acadêmicos elencados acima.

Rio de Janeiro, 22 de maio de 2017.

Atenciosamente,

João Fragoso

Professor do Instituto de História Universidade Federal do Rio de Janeiro. Rio de Janeiro, RJ, Brasil. 